\title{
Euphorbia helioscopia Inhibits the LPS-Induced Pro-Inflammatory Response in RAW 264.7 Cells via the NF-KB and MAPK Pathway
}

\author{
EUN-JIN YANG, JUYEONG LEE, DUK SOO KIM, NAM HO LEE and CHANG-GU HYUN*
}

\author{
Cosmetic Sciences Center, Department of Chemistry and Cosmetics, \\ Jeju National University, Jeju 63243, Korea. \\ ${ }^{*}$ Corresponding author E-mail: cghyun @ jejunu.ac.kr \\ http://dx.doi.org/10.13005/ojc/320605
}

(Received: October 02, 2016; Accepted: November 29, 2016)

\begin{abstract}
Previous studies have characterized the total polyphenolic contents, antioxidant activity, tyrosinase, elastase, and NO production of halophytes. Halophytes are distributed among many countries; however, it has not been properly utilized. In this study, we investigated the inhibitory effect of halophyte Euphorbia helioscopia (E.H.) on the LPS-induced inflammatory response in RAW 264.7 macrophages by MTT assay, NO assay, ELISA, and western blot analysis. Our results demonstrate that E.H. reduced LPS-induced $\mathrm{NO}$ and $\mathrm{PGE}_{2}$ in addition to pro-inflammatory mediators, IL-6, IL-1 $\beta$ and TNF- $\alpha$. Furthermore, E.H. inhibited LPS-induced activation of NF- $\mathrm{KB}$, via $\mathrm{I} \kappa \mathrm{B} \alpha$ degradation and phosphorylation of JNK and ERK. Our data suggest that the E.H. anti-inflammatory effect is a result of inhibition of LPS-induced NO, PGE ${ }_{2}$ IL-6, IL-1 $\beta$, and TNF- $\alpha$ production via downregulation of the $\mathrm{NF}-\kappa \mathrm{B}$ and MAPK pathway.
\end{abstract}

Keywords : Euphorbia helioscopia, halophyte, inflammation, MAPK, NF-kB

\section{INTRODUCTION}

Lipopolysaccharide (LPS)-induced activation of murine RAW 264.7 cells results in the production of pro-inflammatory cytokines including $\mathrm{PGE}_{2}$, IL-6, TNF- $\alpha$, and IL-1 $\beta$. Cytokine production is regulated by cellular signaling events, such as the NF- $\mathrm{KB}$ and MAPK pathway, mediating inflammation, and the immune response to infection ${ }^{1-5}$.
About 1500 species of salt-tolerant halophytes are distributed in the costal wetland of river estuaries, saltpans, and reclaimed land. Moreover, about 40-100 species are distributed in Korea. Halophytes are rich in natural minerals owing to their ability to grow in the soil of seawater ${ }^{6,7}$.

We recently characterized the total polyphenolic content, antioxidant activity, tyrosinase, 
elastase, and nitric oxide (NO) production of 21 halophyte species in vitro 8 . Among them, Euphorbia helioscopia (E.H)., used as traditional Chinese medicine, and its extracts were found to inhibit various carcinomas, in addition to having antifungal and antibacterial activity ${ }^{9,10}$. However, there have been no reports on its anti-inflammatory activity. Therefore, we evaluated the effect of E.H. on NO, iNOS, and pro-inflammatory cytokine production. Further, to establish the anti-inflammatory mechanism for E.H., we examined the NF-kB and MAPK signaling pathways in the murine RAW 264.7 cells.

\section{MATERIALS AND METHODS}

\section{Cells and reagen}

A RAW 264.7 mouse macrophage cell line was obtained from the Korean Cell Line Bank (Seoul, Korea). Cells were cultured in Dulbecco's Modified Eagle's medium (DMEM containing $2 \mathrm{mM}$ glutamine, $10 \mathrm{mM}$ HEPES, $100 \mu \mathrm{g} / \mathrm{mL}$ penicillin-streptomycin, and $10 \%$ fetal bovine serum (FBS) at $37^{\circ} \mathrm{C}$ under 5 $\% \mathrm{CO}_{2}$ in a humidified incubator. Lipopolysaccharide (LPS) was purchased from Sigma Aldrich (St. Louis, MO, USA). For ELISA, IL-6, PGE ${ }_{2}, I L-1 \beta$ and TNF- $\alpha$ were obtained from R\&D Systems (St. Louis, MO, USA). Anti-iNOS antibody and anti-COX-2 antibody were purchased from BD Bioscience (San Diego, CA, USA). All other antibodies were purchased from Cell Signaling Technology (Beverly, MA, USA).

\section{MTT cell viability assay}

RAW 264.7 macrophage cells were cultured in 96-well plates for $18 \mathrm{~h}$, followed by treatment with various concentrations (50 to $200 \mu \mathrm{g} / \mathrm{mL}$ ) of the $E$. helioscopia for $24 \mathrm{~h}$. Cell viability was then perforemed by 3-(4,5-dimethylthiazol-2yl),5-diphenyltetrazolium bromide (MTT) assay ${ }^{11,12}$. Formazan crystals were dissolved in dimethyl sulphoxide (DMSO) and percent cytotoxicity was determined relative to the untreated control group.

\section{Nitric oxide assay}

Nitrite levels was used as an indicator of NO production in the cell culture medium by the Griess reagent ( $1 \%$ sulfanilamide, $0.1 \%$ naphthylethylenediamine dihydrochloride, and 2.5\% phosphoric acid) ${ }^{13,14}$. Specifically, culture supernatant from each well was mixed with equal volume Griess reagent for $15 \mathrm{~min}$, and optical density was determined at $540 \mathrm{~nm}$. Percent NO production was determined relative to the control LPS only treated group.

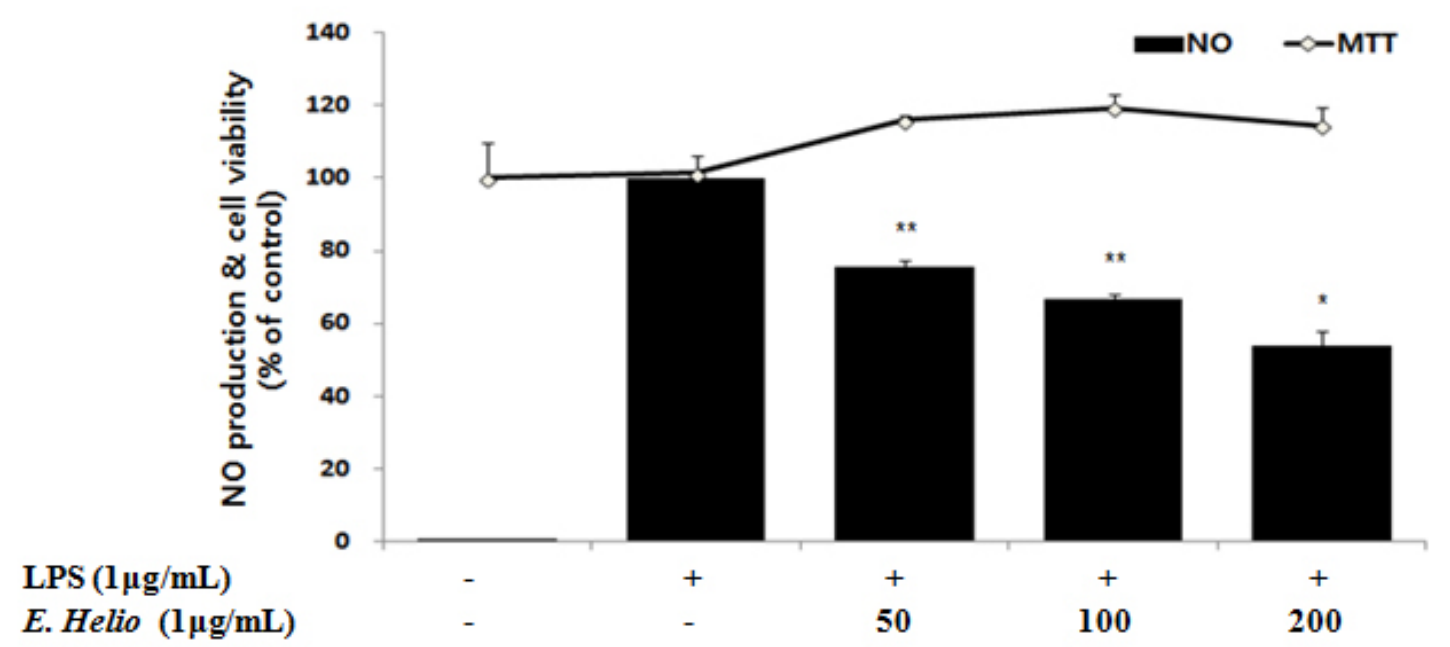

Cells were treated with $1 \mu \mathrm{g} / \mathrm{mL}$ of LPS or with LPS plus various concentrations (50 to $200 \mu \mathrm{g} / \mathrm{mL}$ ) of $E$. helioscopia for $24 \mathrm{~h}$. Nitric oxide (NO) production was determined by the Griess reagent method. Cell viability was determined from the $24 \mathrm{~h}$ culture of cells treated with LPS $(1 \mu \mathrm{g} / \mathrm{mL})$ in the presence of E. helioscopia. The data represent the mean \pm SD of triplicate experiments. ${ }^{*} p<0.005$, ${ }^{* *} p<0.001$ versus LPS alone.

Fig. 1: Effect of Euphorbia helioscopia on nitric oxide production in LPS-treated RAW 264.7 cells 


\section{ELISA determination of cytokines}

Cells $\left(1 \times 10^{6}\right)$ were cultured for $24 \mathrm{~h}$ in the presence or absence of $1 \mu \mathrm{g} / \mathrm{mL}$ LPS and various concentrations of $E$. helioscopia $(50,100$, $200 \mu \mathrm{g} / \mathrm{mL}$ ). Cell supernatants were harvested and centrifuged at 4,500 rpm for $4 \mathrm{~min}$ to remove dead cells. Cytokine production percent was determined relative to the control LPS only treated group.

\section{Western blot analysis}

Cells were washed twice with cold PBS, followed by lysis in RIPA lysis buffer on ice for $20 \mathrm{~min}$. Cell lysates were centrifuged at $12,000 \mathrm{rpm}$ for $20 \mathrm{~min}$ at $4^{\circ} \mathrm{C}$ and protein concentration was determined using the BCA method. Cell lysates were separated by $8 \%$ Bis-Tris gel and transferred with the iBlot 7-minute blotting system to iBlot Gel transfer stacks (ThermoFisher Scientific, USA). The membrane was blocked using $5 \%$ skim milk for 1 $\mathrm{h}$ at room temperature, followed by an overnight incubation at $4^{\circ} \mathrm{C} 2 \mathrm{~h}$ with 1:1000 dilution primary antibody. Following four washes, the membranes were incubated with 1:5,000 dilution of horseradish peroxidase-conjugated secondary antibody for 30 $\mathrm{min}$ at room temperature. Membrane proteins were detected using the ECL western blotting detection substrate.

\section{LPS $(1 \mu \mathrm{g} / \mathrm{mL})$ E. Helio $(1 \mu \mathrm{g} / \mathrm{mL})$

$\begin{array}{ll}- & + \\ - & -\end{array}$

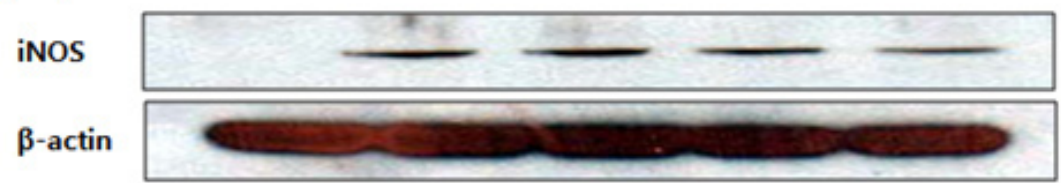 \\ 130 kDa \\ 42 kDa}

RAW 264.7 cells $\left(6.0 \times 10^{5}\right.$ cell $\left./ \mathrm{mL}\right)$ treated with LPS $(1 \mu \mathrm{g} / \mathrm{mL})$ in the presence of $E$. helioscopia (50 to 200 $\mu \mathrm{g} / \mathrm{mL})$ for $24 \mathrm{~h}$. Whole-cell lysates $(30 \mu \mathrm{g})$ were prepared, protein was subjected to $8 \%$ SDS-PAGE, and expression of iNOS and control â-actin was determined by western blotting.

Fig. 2: Effect of Euphorbia helioscopia on the protein level of iNOS in LPS-treated RAW 264.7 cells

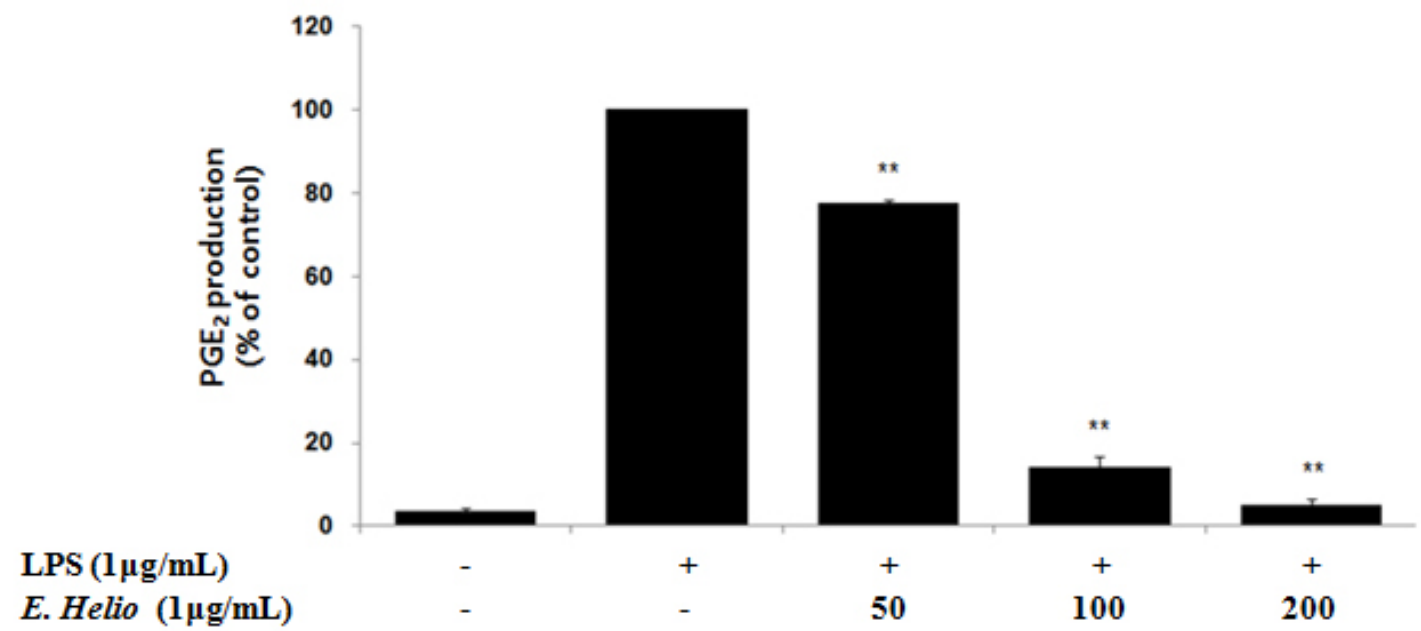

Cells were treated with $1 \mu \mathrm{g} / \mathrm{mL}$ of LPS or with LPS plus various concentrations (50 to $200 \mu \mathrm{g} / \mathrm{mL}$ ) of $E$. helioscopia for $24 \mathrm{~h}$. $\mathrm{PGE}_{2}$ production was determined by ELISA. The data represent the mean $\pm \mathrm{SD}$ of triplicate experiments. ${ }^{\star} p<0.005,{ }^{\star *} p<0.001$ versus LPS alone. $\mathrm{IC}_{50}=75.4 \mu \mathrm{g} / \mathrm{mL}$

Fig. 3: Effect of Euphorbia helioscopia on $\mathrm{PGE}_{2}$ production in LPS-treated RAW 264.7 cells 

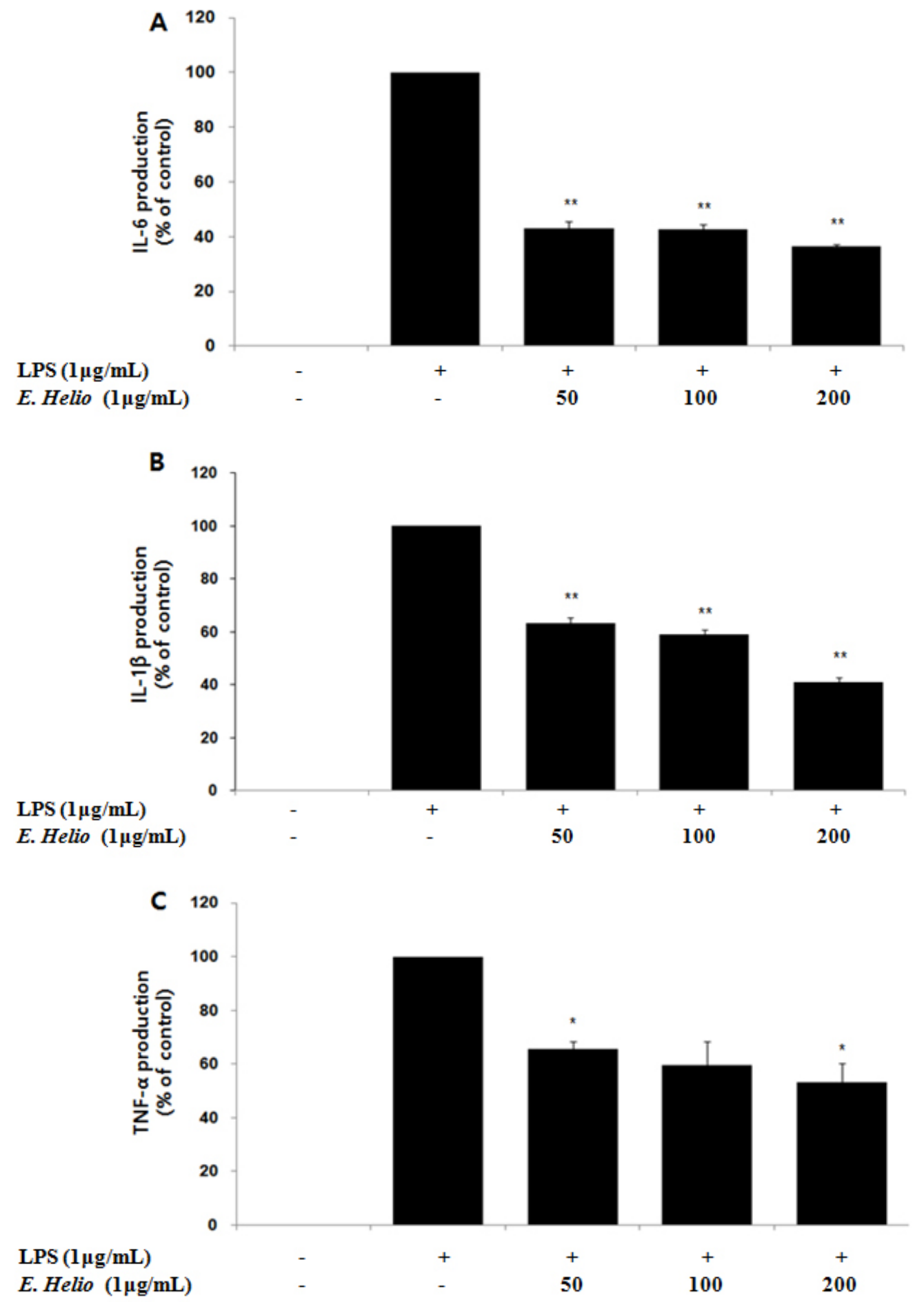

Fig. 4: Effect of Euphorbia helioscopia on IL-6, IL-1 $\beta$, and TNF- $\alpha$ production in LPS-treated RAW 264.7 cells

Cells were stimulated with $1 \mu \mathrm{g} / \mathrm{ml}$ of LPS or with LPS plus various concentrations $(50,100,200 \mu \mathrm{g} / \mathrm{mL})$ of E. helioscopia for $24 \mathrm{~h}$. IL-6 (A), IL-1 $\beta$ (B), and TNF- $\alpha$ (C) productions were determined by ELISA. The data represent the mean \pm SD of triplicate experiments. ${ }^{*} p<0.005,{ }^{* *} p<0.001$ versus LPS alone. 


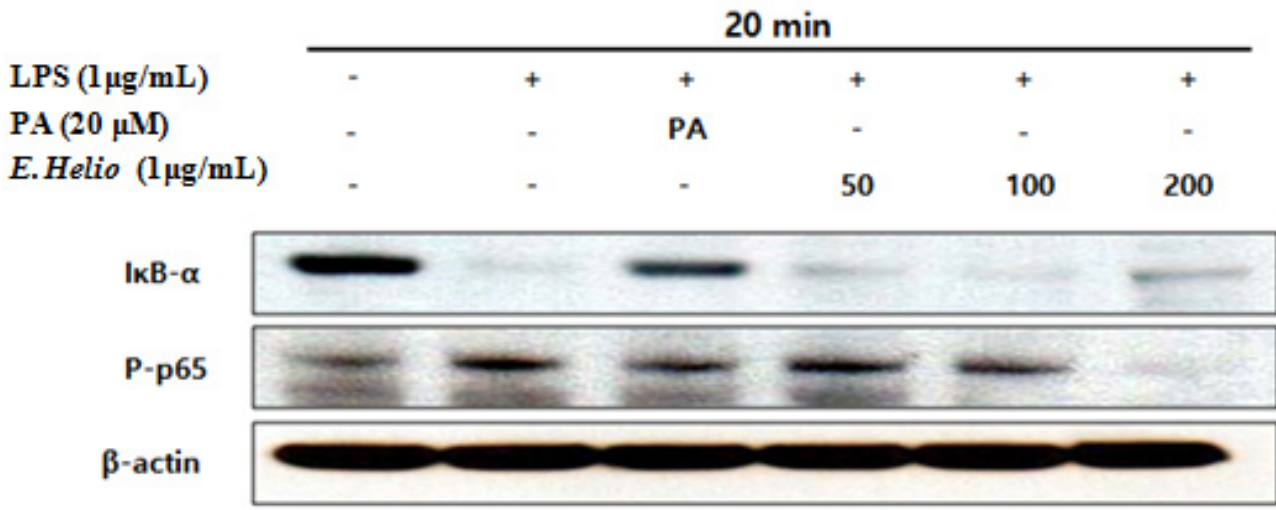

39 kDa

65 kDa

42 kDa

RAW 264.7 cells $\left(1.0 \times 10^{6}\right.$ cells $\left./ \mathrm{mL}\right)$ were treated with LPS $(1 \mu \mathrm{g} / \mathrm{mL})$ in the presence of E. helioscopia (50 to $200 \mu \mathrm{g} / \mathrm{mL})$ or palmitate $(20 \mu \mathrm{M})$ for 20 minutes. Whole cell lysates $(30 \mu \mathrm{g})$ were prepared, protein was subjected to $8 \%$ SDS-PAGE, and expression of $1 \kappa B \alpha$, P-p65 and control $\beta$-actin was determined by western blotting

Fig. 5: Effect of halophyte Euphorbia helioscopia on the degradation of

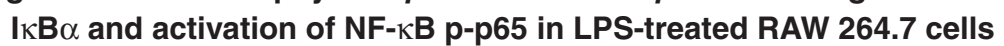

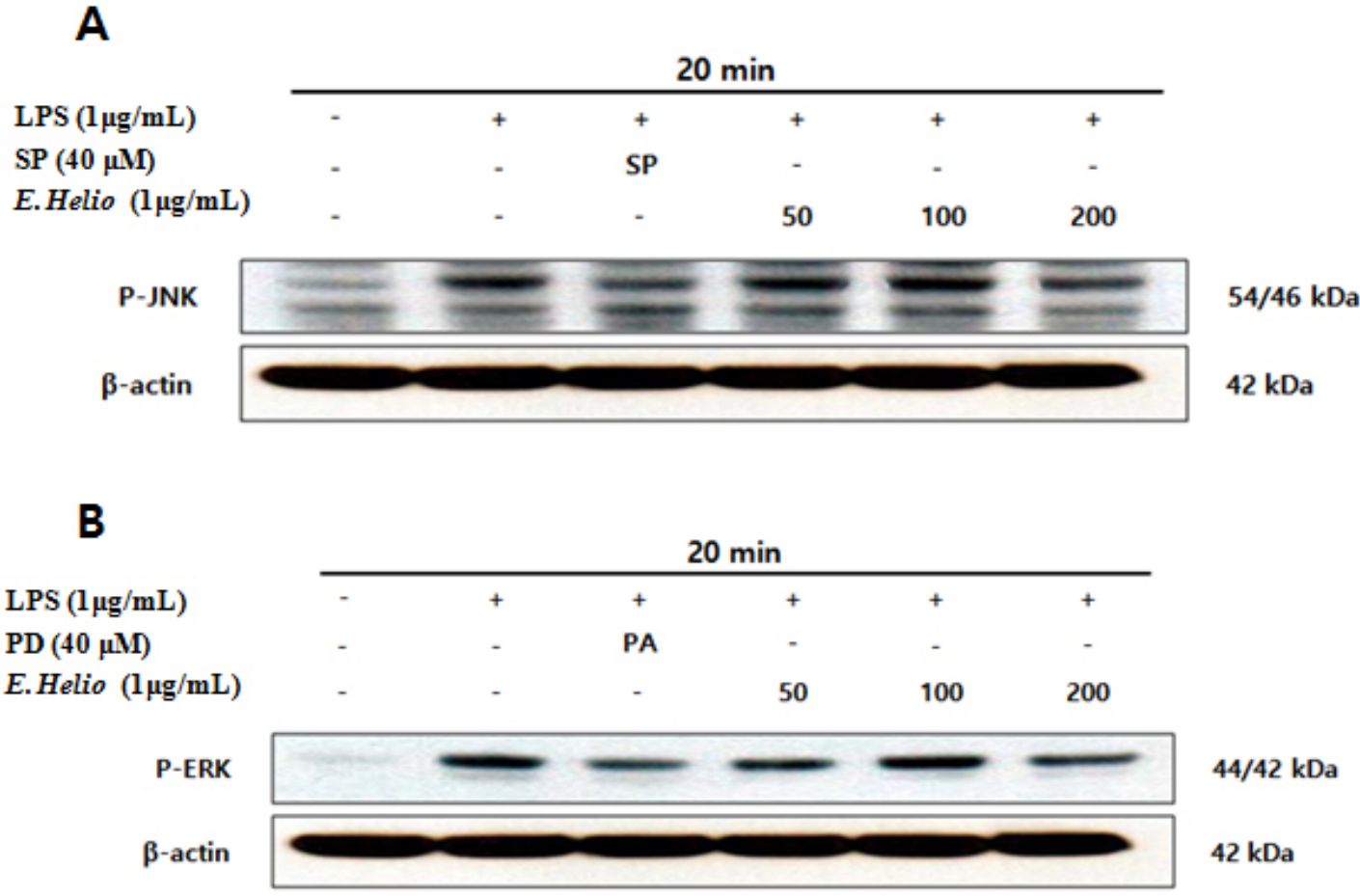

Fig. 6: Effect of Euphorbia helioscopia on the phosphorylation of JNK (A) and ERK (B) in LPS-treated RAW 264.7 cells

RAW 264.7 cells $\left(1.0 \times 10^{6}\right.$ cells $\left./ \mathrm{mL}\right)$ were treated with LPS $(1 \mu \mathrm{g} / \mathrm{mL})$ in the presence of E. helioscopia (50 to $200 \mu \mathrm{g} / \mathrm{mL})$ or inhibitors $(40 \mu \mathrm{M})$ for 20 minutes. Whole cell lysates $(30 \mu \mathrm{g})$ were prepared, protein was subjected to $10 \%$ SDS-PAGE, and expression of p-JNK, p-ERK and control â-actin was determined by western blotting. SP600125 (SP): JNK inhibitor, PD98059 (PD): ERK inhibitor. 


\section{Data analysis}

All data were expressed as the mean \pm standard deviation (S.D) of at least 3 replicates. The Student's $t$-test and one-way ANOVA were used for statistical analysis, and ${ }^{*} P<0.005,{ }^{* *} P<0.001$ was considered significant.

\section{RESULTS}

Effect of E. helioscopia on the cell viability and NO production of RAW 264.7 cells

We investigated the effect of E.H. on LPStreated RAW 264.7 cells after $24 \mathrm{~h}$ by cell viability and NO production. We found that E.H. was not cytotoxic to LPS-treated RAW 264.7 cells at concentrations up to $200 \mu \mathrm{g} / \mathrm{mL}$ by MTT assay (Figure 1). To investigate the anti-inflammatory effects of E.H., we analyzed LPS-induced NO production in E.H.-treated cells. Cells were treated with $1 \mu \mathrm{g} / \mathrm{mL}$ of LPS and various concentration of E.H. for $24 \mathrm{~h}$ and NO levels in the media were determined. We found that E.H. reduced NO production in LPS-treated cells in dose dependent manner (Figure 1). We utilized western blot analysis to determine if the inhibitory effect of E.H. on NO production was due to a reduction in iNOS expression. As expected, LPS markedly induced iNOS protein levels; however, treatment with E.H. inhibited iNOS expression in LPS-treated cells suggesting that the inhibitory effect of E.H. on LPSinduced NO production was due to the suppression of iNOS (Figure 2).

\section{Effect of E. helioscopia on the LPS-induced PGE production}

$\mathrm{PGE}_{2}$ is a pro-inflammatory mediator implicated in many different inflammatory diseases. To analyze the inhibitory effect of E.H. on the production of $P G E_{2}$, we utilized ELISA. We found that $\mathrm{E} . \mathrm{H}$. significantly reduced $\mathrm{PGE}_{2}$ production by $90 \%$ in the LPS stimulated RAW 264.7 cells (Figure 3).

\section{Effect of E. helioscopia on the LPS-induced pro- inflammatory cytokine production}

To determine if E.H. reduces LPS-induced pro-inflammatory cytokines IL-6, IL-1 $\beta$ and TNF- $\alpha$ production, we utilized ELISA. We found that E.H. strongly inhibited IL-6, IL-1 $\beta$ and TNF- $\alpha$ production in the LPS-treated RAW 264.7 cells by $63.6 \%, 58.9 \%$ and $46.6 \%$, respectively (Figure 4 ).
Effect of $E$. helioscopia on the LPS-induced NF- $\kappa \mathrm{B}$ activation and $\mathrm{I}_{\kappa} \mathrm{B} \alpha$ degradation

Activation of $\mathrm{NF}-\kappa \mathrm{B}$ is critical for the production of iNOS, PGE ${ }_{2}$, IL-6, IL-1 $\beta$, and TNF- $\alpha$ in LPS-treated murine RAW 264.7 macrophages. $I_{\kappa} \mathrm{B} \alpha$ phosphorylation and degradation is required for NF- $\kappa B$ activation ${ }^{15}$. To determine if E.H.-induced $N F-\kappa B$ inhibition is due to $I_{\kappa} B \alpha$ phosphorylation and degradation, we analyzed cytoplasmic levels of NF$\kappa \mathrm{B}$. As expected, LPS treatment led to a reduction of I $\mathrm{B} \alpha$ levels; however, treatment with E.H. weakly blocked the LPS-induced I $\mathrm{B} B \alpha$ degradation. Further, we found that E.H. significantly suppressed LPSinduced phosphorylation of $\mathrm{NF}-\kappa \mathrm{B}$ in cytoplasm (Figure 5).

\section{Effect of E. helioscopia on the LPS-induced JNK and ERK phosphorylation \\ The MAPK pathway plays an important role} in the activation of $\mathrm{NF}-\kappa \mathrm{B}(15,16)$. To investigate whether the E.H.-induced NF- $\mathrm{KB}$ inhibition is mediated through the MAPK pathway, we analyzed LPS-induced p-JNK and p-ERK kinase expression in E.H.-treated RAW 264.7 cells. E.H. suppressed LPS-induced activation of $p$-JNK and $p$-ERK while the expression of non-phosphorylated JNK and ERK was unaffected by both LPS or LPS plus E.H treatment (Figure 6).

\section{CONCLUSION}

Both $\mathrm{NO}$ and $\mathrm{PGE}_{2}$, produced by activated macrophages, play critical roles in inflammatory diseases. In the present study, we found that E.H. inhibits $\mathrm{NO}$ and $\mathrm{PGE}_{2}$ production, in addition to iNOS expression, in dose dependent manner. The inhibition of NO, $\mathrm{PGE}_{2}$ and iNOS was not due to E.H.induced cytotoxicity as cell viability was unaffected when assessed by MTT assay.

Pro-inflammatory cytokines, such as, IL-6, IL-1 $\beta$ and TNF- $\alpha$, pro-inflammatory are associated with the immunopathology of inflammatory diseases such as rheumatism and various autoimmune diseases. In this study, we found that E.H. significantly inhibited IL-6, IL-1 $\beta$ and TNF- $\alpha$ production. NF- $\mathrm{KB}$ plays a critical role in regulating $\mathrm{NO}, \mathrm{PGE}_{2}$ and pro-inflammatory cytokines. To determine if E.H.-induced inhibition of NO, PGE ${ }_{2}$, IL-6, IL-1 $\beta$, and TNF- $\alpha$ result from the inhibition of 


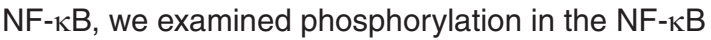
and MAPK pathways. We found that the activity of p65, JNK and ERK was inhibited by E.H. in LPStreated RAW 264.7 cells.

These data suggest that the E.H.-induced phosphorylation in the MAPK pathway may contribute to its inhibitory effect on NF-кB in E.H.-treated RAW 264.7 cells. Further, E.H. may block LPS-induced $I_{\kappa} \mathrm{B} \alpha$ degradation, inhibiting NF- $\kappa \mathrm{B}$ activation.

In summary, our findings suggest that E.H. is a potent inhibitor of LPS-induced NO, PGE, IL-6, IL-1 $\beta$, and TNF- $\alpha$ production in RAW 264.7 cells. Moreover, the inhibitory effect of E.H. was found to be associated with NF-кB inactivation via blockade of lêBá phosphorylation and degradation.

This study is the first to provide evidence that $E$. helioscopia inhibits $\mathrm{NO}, \mathrm{PGE}_{2}$ and proinflammatory mediators in LPS-treated RAW 264.7 cells via the blockade of the NF- $\mathrm{BB}$ and MAPK pathways.

\section{ACKNOWLEDGEMENTS}

This research was supported by the 2016 Scientific Promotion Program funded by Jeju National University.

\section{REFERENCES}

1. Fang, H.; Pengal, R.A.; Cao, X.; Ganesan, L.P.; Wewers, M.D.; Marsh, C.B.; Tridandapani, S.; J. Immunol. 2004, 173, 360-366.

2. Agrawal, D.K.; Shao, Z.; Curr. Allergy Asthma Rep. 2010, 10, 39-48.

3. Kim, M.J.; Yang, K.W.; Yang, E.J.; Kim, S.S.; Park, K.J.; An, H.J.; Choi, Y.H.; Lee, N.H.; Hyun, C.G.; Orient. J. Chem. 2015, 31, 19151922.

4. Yang, E.J.; Hyun, G.H.; Kim, H., Kim, M.J.; Lee, N.H.; Hyun, C.G.; Orient. J. Chem. 2016, 32, 29-35.

5. Hyun, E.A.; Kang, J.S.; Yang, K.W.; Kim, S.Y.; Kim, S.C.; Lee, W.J.; Lee, N.H.; Hyun, C.G.; Orient. J. Chem. 2016, 32, 1749-1757.

6. Jeong, J.H.; Kim, T.K.; Choi W.Y.; Kim, S.R.; Development Administration RDA Interrobang, 2014, 1-15 (Korean)

7. Kong, C.S. Prev. Nutr. Food Sci. 2014, 19, 261-267.

8. Yang, E.J.; Hyun, J.M.; Lee, N.H.; Hyun, C.G.;
Int. J. ChemTech Res. 2016, 9, 541-547.

9. Cheng, J.; Han, W.; Wang, Z.; Shao, Y.; Wang, Y.; Zhang, Y.; Li, Z.; Xu, X.; Zhang, Y.; BioMed Res. Int. 2015, 2015, 601015.

10. Wang, Z.Y.; Liu, H.P.; Zhang, Y.C.; Guo, L.Q.; Li, Z.X.; Shi, X.F.; Anat. Rec. (Hoboken), 2012, 295, 223-233.

11. Gerlier, D.; Thomasser, N.; J. Immunol Methods. 1986, 94, 57-63.

12. Liu, Y. Prog. Neuropsychopharmacol. Biol. Psychiatry. 1996, 23, 377-395.

13. Snell, J.C.; Colton, C.A.; Chernvshev, O.N.; Gilgert, D.L.; Free Radic. Biol. Med, 1996, 20, 361-363.

14. Woo, E.R.; Lee, J.Y.; Cho, I.J.; Kim, S.G.; Kang, K.W.; Pharmacol. Res. 2005, 51, 539546.

15. Guha, M.; Mackman, N.; Cell Signal. 2001, 13, 85-94.

16. Irie, T.; Muta, T.; Takeshige, K.; FEBS Lett. 2000, 467, 160-164. 